\title{
"A Study On Growth Parameters And Prevalence Of Overweight And Obesity Among School Going Children (5 - 10 Years) In Tirunelveli District"
}

\author{
J. Harine Sargunam ${ }^{\#}$, M.A.S. Haseen Fathima ${ }^{\#}$,Dr.M.I. Fazal Mohamed ${ }^{\#}$ \\ \# Department of Nutrition and Dietetics, Jamal Mohamed College, Trichy - 620020.
}

\begin{abstract}
Recent data indicate a rise in obesity in children in developing countries. A study in India revealed that among school going children 9.9\% of boys and 12\% of girls were overweight and $6.3 \%$ of the girls were obese. This study highlights the theories of prevalence, assessment dietary significance, clinical effects and inter relation between low socio economic and upper socio economic status of childhood for overweight and obesity. This paper outlined current tools used to assess and identify those who are at risk for overweight and obesity. The current gold standard for assessing and diagnosing overweight and obesity is the Body Mass Index (BMI). This study was designed to know the prevalence of childhood obesity in school children from rural and urban areas in Tirunelveli district. Data on the prevalence of obesity in children were collected and analyzed from two schools from urban and rural areas of Tirunelveli district respectively. The prevalence of childhood obesity in Tirunelveli is not very high as compared to other reports from different regions of the country. However, it is an important multi factorial condition which needs immediate medical attention to stop the march of healthy children towards chronic disorders.
\end{abstract}

\section{Introduction}

Obesity is one of the most prevalent nutritional diseases of children and adolescents in many developed and developing countries. The World Health Organization (WHO) has declared overweight as one of the top ten health risks in the world and one of the top five in developed nations. The term overweight refers to an excess of body weight 10 percent greater than the standard, whereas obesity is used to describe an excess body weight 20 percent or more than the standard. Childhood obesity is a condition where excess body fat negatively affects a child's health or wellbeing. As methods to determine body fat directly are difficult, the diagnosis of Obesity is often based on BMI.

The prevalence of overweight and obesity in urban children in Delhi has shown an increase from 16\% in 2002 to about $24 \%$ in 2006. According to our recent data, the prevalence among adolescent children (14 - 17 years) was $29 \%$ in private schools and $11.3 \%$ in government funded schools in $2006-2007$. Globally an estimated $10 \%$ of school-aged children between 5 to 17 years of age are overweight or obese.

Prevalence of childhood and adolescent obesity and overweight from different parts of India (Punjab, Maharashtra, Delhi and South India) that range from 3\% to 29\% and also indicate that the prevalence is higher in urban than in rural areas. One half of obese school children become obese adults. However, whether or not obesity persists into adulthood, obesity in childhood appears to increase the risk of subsequent morbidity. The proportion of school-age children affected will almost double by 2010 compared with the most recently available surveys from the late 1990s up to 2003. Children were categorized into three groups:

Obese $\left(>95^{\text {th }}\right.$ percentile $)$, Overweight $\left(\geq 85^{\text {th }}\right.$ percentile $)$ and normal $\left(<85^{\text {th }}\right.$ percentile, $>5^{\text {th }}$ percentile $)$ using age - and sex - specific percentiles of BMI.

World Health Organization (WHO) has recommended various indices based on anthropometry to evaluate the nutritional status of children (WHO, 1995). Weight, height and BMI for age are parameters for assessment of nutritional status in children. The BMI is expressed as

BMI = Weight in $\mathrm{kg} /($ Height $)$ in $\mathrm{m}^{2}$

$\mathrm{BMI}$ is an inexpensive and easy-to-perform method of screening for weight categories that may lead to health problems. For children and teens, BMI is age and sex-specific and is often referred to as BMI-for-age. After BMI is calculated for children and teens, the BMI number is plotted on the CDC (National Center for Chronic Disease Prevention and Health Promotion, 2000) BMI-for-age growth charts (for either girls or boys) to obtain a percentile ranking. Percentiles are the most commonly used indicator to assess the size and growth patterns of individual children. The percentile indicates the relative position of the child's BMI number among children of the same sex and age. The growth charts show the weight status categories used with children and teens (underweight, healthy weight, overweight, and obese). BMI-for-age weight status categories and the corresponding percentiles are shown in the following:

Weight status category percentile Range 
Underweight

Healthy weight

Overweight

Obesity

Less than the $5^{\text {th }}$ percentile

5 th percentile to less than the $85^{\text {th }}$

$85^{\text {th }}$ to less than the $95^{\text {th }}$ percentile

Equal to or greater than the $95^{\text {th }}$ percentile

On the other hand, there are supporting evidence that excessive sugar intake by soft drink, increased portion size, and steady decline in physical activity have been playing major roles in the rising rates of obesity all around the world. Consequently, both over-consumption of calories and reduced physical activity are involved in childhood obesity. Consumption of foods prepared away from home often represents a diet that is high in fat and energy. Meals provided through school cafeteria have also been shown to contain more fat than recommended. Fast foods are one of the most advertised products on television and children are often the targeted market. When outdoor activities of the children are compared with their BMI status, there is significantly higher prevalence of overweight and obesity in children with only indoor activities such as television viewing (>20hrs/week), computer and video games (>10hrs/week), indoor games(>10hrs/week) sleeping (>10hrs/day) and long school hours. Increases in active modes of transport to and from school (walking, cycling, and public transport) would require policy changes at the school and local government levels, as well as support from parents and the community.

A major concern about childhood obesity is that obese children appear more likely to become obese adults, who carry serious risks of obesity-related chronic conditions such as Type II diabetes, coronary heart disease, hypertension, gallbladder disease, breast cancer, endometrial cancer, colon cancer, and osteoarthritis. The immediate consequences of overweight in childhood are often psychosocial and also include cardiovascular risk factors such as hypertension, high blood cholesterol, and abnormal glucose tolerance. Overweight and obese children have higher blood pressure, more abnormalities in serum lipid levels and higher levels of insulin resistance than children of a normal weight. All of these conditions are hall marks of early metabolic disease and susceptibility to atherosclerosis and other cardiovascular diseases. Obesity is an independent risk factor for cardiovascular diseases and significantly increases the risk of morbidity and mortality. Many co-morbid conditions like metabolic, cardiovascular, psychological, orthopaedic, neurological, hepatic, pulmonary and renal disorders are seen in association with childhood obesity. Overweight and obesity in childhood have significant impact on both physical and psychological health. Early menarche is clearly associated with extent of obesity, with a two-fold increase in rate of early menarche associated with BMI greater than the 85 th percentile. Childhood obesity can prove to be a life-threatening condition over a period of time. With growing age, the problems may become more severe. They may also face problems such as lack of stamina, and bones and joint problems due to their overweight body mass. The increased technology in the lives of children appears to be associated with the rise in obesity.

Another problem causing this epidemic is unhealthy eating habits encouraged by fast food restaurants, candy and soda. Other causes stated by professionals include genetic, hormonal, and neurological. In addition, obesity prevalence varies across socio-economic strata. In developed countries, children of low socio-economic status are more affected than their affluent counterparts. The opposite is observed in developing countries where children of the upper socio-economic strata are more likely than poor children to be obese. Socio-economic trends in childhood obesity in India are also emerging. A study from northern regions of India reported a childhood obesity prevalence of 5.59 percent in the higher socio-economic strata when compared to 0.42 percent in the lower socio-economic strata. Urbanization related intake behaviours that have been shown to promote obesity include frequent consumption of meals at fast-food outlets, consumption of oversized portions at home and at restaurants, consumption of high calorie foods, such as high-fat, low-fibre foods and intake of sweetened beverages. These behaviours are cultivated in an environment in which high calorie food is abundant, affordable, available, and easy to consume with minimal preparation as is the case of urban cities throughout the country. According to one recent nationally representative sample, obesity prevalence was higher in lower income and education groups, but the rate of increase in obesity over two decades was faster for higher income and education groups. The World Health Organization has referred to obesity as a "global epidemic".

\section{Selection of Area}

\section{Methodology}

A cross sectional study was conducted in Tirunelveli District. School children from both sexes in the age group of 5-10 years, belonging to Government school (Rahmania Primary School, Melepalayam) and Private school (CSI Matriculation School, Palayamkottai) were studied.

\section{Selection of the Sample}

The children attending Government school were considered to represent the Low Socio Economic Status (LSES), while those attending Private school were considered representative of the Upper Socio 
Economic Status (USES). Of the above 250 subjects, 125 belonged to Low Socio Economic Status (LSES) group, and 125 made up the Upper Socio Economic Status (USES) group.

\section{Selection of Method}

\section{A) Dietary survey}

A dietary survey is an important part of the nutritional assessment, as it is observation of the current intake of the selected subjects. Data regarding, type of food consumption, dietary habits, frequency of consumption of meal, nutrient intake of the subjects were assessed by 24 hours recall method on same individual often provided more accurate estimates of typical intake. Hence nutrient intake for three days was assessed.

\section{B) Anthropometric measurements}

A prior consent for the study was taken from the school administration and from the parents. At the time of initiating the study the parents of each participant were informed about the study and gave written consent to their children's participation. The entire 250 children underwent assessment of height and weight and calculation of BMI. Height was measured to the nearest $0.1 \mathrm{~cm}$ using a measuring tape with the subject standing straight. Subject's weight, without shoes and with light clothes on was measured to the nearest $0.1 \mathrm{~kg}$, using bathroom weighing balance. Height and weight measurements were taken twice and the mean of two measurements was used to calculate BMI, which was defined as the ratio of body weight to body height squared, expressed in $\mathrm{kg} / \mathrm{m} 2$. Every morning, the weighing balance and measuring tape were calibrated with standard weight and height respectively.

The cut off values of BMI, at each age and for each gender obtained were used to classify children as Normal, Overweight and Obese. Prevalence of over-weight and obesity was assessed for Low Socio Economic Status (LSES) group, and Upper Socio Economic Status (USES) group at each age group and for both sexes. Finally, a comparison of the prevalence of overweight and obesity in Lower Socio Economic Status (LSES) and Upper Socio Economic Status (USES) was done for each age group for both sexes.

\section{ANALYSIS OF DATA}

Data was recorded on a pre-designed proforma. Height, weight and BMI percentile charts specific for the socio economic status were generated using the CDC method. Currently, this is the recommended method for establishing percentiles. Descriptive statistics for anthro-pometric variables were computed by mean and standard deviation. To see the significant difference between two groups of continuous variables student $t$-test and chi square test was applied. P value $<0.001$ was considered statistically significant.

\section{Result And Discussion}

The hypothesis developed for the present study is as follows: subjects.

1. There will be a significant difference between the nutritional intakes of the selected

2. There will be a significant difference between the height, weight and BMI distribution of the selected subjects.

In tables 1 to 9 following abbreviations are used.

LSES - Low Socio Economic Status

USES - Upper Socio Economic Status

\section{1) Dietary survey}

The nutritional statuses of the selected subjects are usually influenced by their physiological status which intern is influenced by dietary habits. The mean nutrient intake of the selected subjects is given in the Table -1

The sub sample comprised of 25 from LSES and 25 from USES assessed of their nutrient intake using 24 hours recall method. The amount of various nutrients present in the diet was calculated and the mean nutrient intake was compared with RDA. Table 1showed the mean nutrient intake of the selected subjects. 
“A Study On Growth Parameters And Prevalence Of Overweight And Obesity Among School Going

Table 1: Mean Nutrient Intake of the Selected Subjects

\begin{tabular}{|c|c|c|c|c|c|c|}
\hline Nutrients & $\begin{array}{c}\text { Socio economic } \\
\text { Status }\end{array}$ & Mean \pm SD & RDA* & $\begin{array}{c}\% \text { Excess/ } \\
\text { Deficit }\end{array}$ & $\begin{array}{c}\text { "t" } \\
\text { Value }\end{array}$ & $\begin{array}{l}\text { Level of signifi } \\
\text { cance }\end{array}$ \\
\hline \multirow{2}{*}{$\begin{array}{c}\text { Energy } \\
\text { (K.cal/d) }\end{array}$} & LSES & $973.4 \pm 187.85$ & 1950 & -976.6 & \multirow{2}{*}{10.94} & \multirow{2}{*}{$5 \%\left(\mathrm{~S}^{*}\right)$} \\
\hline & USES & $1551.63 \pm 185.64$ & 1950 & -398.37 & & \\
\hline \multirow[b]{2}{*}{$\begin{array}{l}\text { Protein } \\
\text { (g/d) }\end{array}$} & LSES & $30.7 \pm 161.35$ & 41 & -10.3 & \multirow[b]{2}{*}{0.331} & \multirow[b]{2}{*}{$5 \%$ (NS*) } \\
\hline & USES & $41.41 \pm 7.37$ & 41 & +0.42 & & \\
\hline \multirow{2}{*}{ Fat (g/d) } & LSES & $31.7 \pm 9.46$ & 25 & +6.7 & \multirow{2}{*}{2.32} & \multirow{2}{*}{$5 \%\left(\mathrm{~S}^{*}\right)$} \\
\hline & USES & $47.21 \pm 14.90$ & 25 & +22.21 & & \\
\hline \multirow{2}{*}{$\begin{array}{c}\text { Calcium } \\
(\mathrm{mg} / \mathrm{d})\end{array}$} & LSES & $328.35 \pm 43.93$ & 400 & -71.65 & \multirow{2}{*}{0.461} & \multirow{2}{*}{$5 \%\left(\mathrm{NS}^{*}\right)$} \\
\hline & USES & $368.06 \pm 242.07$ & 400 & -31.94 & & \\
\hline \multirow{2}{*}{$\begin{array}{c}\text { Iron } \\
\text { (mg/d) }\end{array}$} & LSES & $5.55 \pm 4.98$ & 26 & -20.45 & \multirow{2}{*}{4.09} & \multirow{2}{*}{$5 \%\left(\mathrm{~S}^{*}\right)$} \\
\hline & USES & $13.42 \pm 8.23$ & 26 & -12.58 & & \\
\hline
\end{tabular}

From the table, $5 \%$ table value $=\mathbf{1 . 9 6}$

*NS - Not significant (accepted i.e., value obtained is lower than the 5\% " $t$ " value)

*S - Significant (rejected i.e., value obtained is higher than the $5 \%$ " $t$ " value)

*RDA - Recommended Dietary Allowances.

The mean energy intakes of the selected subjects were calculated. While compared with RDA, the subjects had a deficit percent of both LSES and USES were -976.6 and -398.37. The mean protein intakes of the selected subjects were calculated. It is compared with RDA, the subjects had a deficit percent of -10.3 for LSES and the subject had an excess percent of +0.42 for USES. The mean fat intakes of the selected subjects were calculated. While compared with RDA, it was found to be the subjects had an excess percent of both LSES and USES were +6.7 and +22.21 . The mean calcium intakes of the selected subjects were calculated. It is compared with RDA, it was found to be the subjects had a deficit percent of both LSES and USES were -71.65 and -31.94. The mean iron intakes of the selected subjects were calculated. It is compared with RDA, it was found to be the subjects had a deficit percent of both LSES and USES were -20.45 and -12.58 in their iron intake.

From the above statistical analysis the hypothesis developed for the nutrient intake of selected subjects was found to be calcium and protein are accepted but energy, fat and iron are rejected.

\section{2) Anthropometric measurement}

Anthropometric measurements are often used, particularly in epidemiologic studies, as indirect methods to estimate the size of fat mass. The most commonly used of these measurements are stature (height), weight and skin fold thickness measurements. Anthropometric measurements of the selected subjects were tabulated.

A total of 250 children in the age group 5 to 10 years were evaluated for height, weight and BMI. These included 125 (59 boys, 66 girls) from the LSES and 125(59 boys, 66 girls) from the USES. Percentile charts for height, weight and BMI were constructed separately for LSES and USES children. These charts depicted the $3^{\text {rd }}, 25^{\text {th }}, 50^{\text {th }}, 75^{\text {th }}$ and $90^{\text {th }}$ percentile for height, weight and BMI.

Height:

Tables $2 \& 3$ depict the percentiles for height for boys and girls for both socioeconomic groups. Children from LSES were significantly shorter compared to those belonging to USES. This difference is seen for each age category, across all the percentile values for both the sexes.

Table 2 Percentile of Height Distribution of Boys (5-10 Years)

\begin{tabular}{|c|c|c|c|c|c|c|c|c|c|c|}
\hline \multirow{2}{*}{$\begin{array}{c}\text { Age in } \\
\text { years }\end{array}$} & \multicolumn{3}{|c|}{3} & \multicolumn{2}{|c|}{25} & \multicolumn{2}{c|}{50} & \multicolumn{2}{c|}{75} & \multicolumn{2}{c|}{90} \\
\cline { 2 - 12 } & LSES & USES & LSES & USES & LSES & USES & LSES & USES & LSES & USES \\
\hline 5 & 97 & 114.5 & 103.7 & - & - & 107.5 & - & - & - & 115 \\
\hline 6 & 98.85 & - & 107 & 116.7 & - & 114.5 & - & 119 & - & 122.2 \\
\hline 7 & 103.4 & - & 116 & - & - & 121.2 & - & 125 & - & 128.7 \\
\hline 8 & 114.1 & - & 124.3 & 121.5 & 127 & 127 & 131 & 130.3 & - & 137.2 \\
\hline 9 & 118 & - & 125.2 & 126.6 & 133 & - & 135 & 137 & - & 141.3 \\
\hline 10 & 121.6 & - & 129 & 132 & - & 136 & 142 & 140.3 & - & 147 \\
\hline
\end{tabular}


Table 3 Percentile of Height Distribution of Girls (5-10 Years)

\begin{tabular}{|c|c|c|c|c|c|c|c|c|c|c|}
\hline \multirow{2}{*}{$\begin{array}{l}\text { Age } \\
\text { in } \\
\text { years }\end{array}$} & \multicolumn{2}{|c|}{3} & \multicolumn{2}{|c|}{25} & \multicolumn{2}{|c|}{50} & \multicolumn{2}{|c|}{75} & \multicolumn{2}{|c|}{90} \\
\hline & LSES & USES & LSES & USES & LSES & USES & LSES & USES & LSES & USES \\
\hline 5 & - & - & 99 & 104.6 & - & 105 & - & 111 & - & 117.2 \\
\hline 6 & - & - & 100.5 & 110.3 & - & 114.5 & - & 117.5 & - & 121.5 \\
\hline 7 & 95 & - & 103.8 & 118 & - & - & - & 123.5 & - & 128 \\
\hline 8 & - & - & 114.1 & 118.7 & - & 126 & 131 & 131.4 & - & - \\
\hline 9 & 115 & - & 120.7 & 122.5 & 131 & 130.8 & - & 134.5 & - & 136.5 \\
\hline 10 & - & - & 126.7 & - & - & 133 & 143 & 141.5 & - & 147.7 \\
\hline
\end{tabular}

It was found that no significant variation was seen in height distribution of boys and girls among low socio economic status and upper socio economic status, in the age group of 5 years, 6 years and 7 years, but height increased gradually among 8 years, 9 years and 10 years of age group. Significant variation was identified among LSES and USES boys and girls at $90^{\text {th }}$ percentile.

\section{Weight:}

Tables 4 \& 5 depict the percentiles for weight for boys and girls for both socioeconomic groups. Children from LSES weighed significantly less compared to those from USES. Once again this difference was seen in both sexes, all age groups and across all percentile values. It was found that no significant variation was seen in weight distribution of boys and girls among low socio economic status and upper socio economic status, in the age group of 5 years, 6 years and 7 years, but weight increased gradually among 8 years, 9 years and 10 years of age group. Significant variation was identified among LSES and USES of both sexes at $90^{\text {th }}$ percentile.

Table 4 Percentile of Weight Distribution of Boys (5-10 Years)

\begin{tabular}{|c|c|c|c|c|c|c|c|c|c|c|}
\hline \multirow{2}{*}{$\begin{array}{c}\text { Age } \\
\text { in } \\
\text { years }\end{array}$} & \multicolumn{2}{|c|}{3} & \multicolumn{2}{|c|}{25} & \multicolumn{2}{|c|}{50} & \multicolumn{2}{|c|}{$\mathbf{7 5}$} & \multicolumn{2}{|c|}{90} \\
\cline { 2 - 11 } & LSES & USES & LSES & USES & LSES & USES & LSES & USES & LSES & USES \\
\hline 5 & 12.8 & - & - & 16.75 & - & 17 & - & 19 & - & 22.33 \\
\hline 6 & 13.57 & 15.5 & 19 & 18.33 & - & $\begin{array}{c}2 \\
0.66\end{array}$ & - & 23 & - & 25 \\
\hline 7 & 15.12 & 17.5 & 19 & 20.5 & - & 21.25 & 27 & 24.83 & - & - \\
\hline 8 & 18.25 & 16.66 & 21.5 & 21.75 & 25 & 25 & - & 27 & - & 36.75 \\
\hline 9 & 22.3 & 21.15 & - & 24.25 & - & 28.75 & - & - & - & 38.33 \\
\hline 10 & 22.37 & - & - & - & - & 30.66 & - & 35.16 & 43 & 43.25 \\
\hline
\end{tabular}

Table 5: Percentile of Weight Distribution of Girls (5-10 Years)

\begin{tabular}{|c|c|c|c|c|c|c|c|c|c|c|}
\hline \multirow{2}{*}{$\begin{array}{l}\text { Age in } \\
\text { years }\end{array}$} & \multicolumn{2}{|c|}{3} & \multicolumn{2}{|c|}{25} & \multicolumn{2}{|c|}{50} & \multicolumn{2}{|c|}{75} & \multicolumn{2}{|c|}{90} \\
\hline & LSES & USES & LSES & USES & LSES & USES & LSES & USES & LSES & USES \\
\hline 5 & - & 13.35 & 11.66 & 15.79 & - & 18.5 & - & 18.54 & - & 23.21 \\
\hline 6 & - & 14.5 & 13.5 & 16 & - & 19.33 & - & 22.12 & - & 25.5 \\
\hline 7 & 13.85 & - & 16.23 & 17.5 & 23.5 & 21.75 & - & 24 & - & 27 \\
\hline 8 & - & 14.26 & 19.64 & 14.93 & 25.5 & 24.5 & 27 & 27 & - & 35 \\
\hline 9 & 21 & - & 21.61 & 20.83 & 25.5 & 27.03 & 29.5 & 30 & 36 & $\mathbf{3 7 . 3 3}$ \\
\hline 10 & - & - & 24.25 & - & 32 & - & - & 35.5 & - & 40.5 \\
\hline
\end{tabular}

BMI:

Tables $6 \& 7$ depict the percentiles for BMI for boys and girls from both socioeconomic strata. The BMI percentiles for children from LSES were significantly lower than those from USES across all age groups and for both sexes. 
Table 6 Percentile of BMI Distribution of Boys (5-10 Years)

\begin{tabular}{|c|c|c|c|c|c|c|c|c|c|c|}
\hline \multirow{2}{*}{$\begin{array}{c}\text { Age in } \\
\text { years }\end{array}$} & \multicolumn{2}{|c|}{3} & \multicolumn{2}{|c|}{25} & \multicolumn{2}{|c|}{50} & \multicolumn{2}{|c|}{75} & \multicolumn{2}{c|}{90} \\
\cline { 2 - 12 } & LSES & USES & LSES & USES & LSES & USES & LSES & USES & LSES & USES \\
\hline 5 & 12.52 & 13.72 & - & 14.77 & - & 16.51 & - & - & - & - \\
\hline 6 & 12.36 & 12.71 & 15.08 & 14.84 & 16.18 & 16.46 & 17.28 & - & 16.90 & - \\
\hline 7 & 13.25 & 12.79 & 14.53 & 15.26 & - & 16.12 & - & - & 18.11 & - \\
\hline 8 & 12.95 & 12.34 & 14.87 & 14.89 & 16.11 & 16.78 & 17.11 & 16.10 & 18.09 & - \\
\hline 9 & 13.78 & 13.73 & 14.87 & 15.34 & - & - & - & 17.34 & - & 19.40 \\
\hline 10 & 14.4 & - & 14.74 & - & - & 16.49 & - & & \multirow{2}{*}{21.32} & 19.31 \\
\hline
\end{tabular}

It was found that no significant variation was seen in BMI distribution of boys and girls among low socio economic status and upper socio economic status, in the age group of 5 years, 6 years and 7 years, but weight increased gradually among 8 years, 9 years and 10 years of age group. Significant variation was identified among LSES and USES boys and girls at $90^{\text {th }}$ percentile.

TABLE 7 Percentile of BMI Distribution of Girls (5-10 Years)

\begin{tabular}{|c|c|c|c|c|c|c|c|c|c|c|}
\hline \multirow{2}{*}{$\begin{array}{l}\text { Age in } \\
\text { years }\end{array}$} & \multicolumn{2}{|c|}{3} & \multicolumn{2}{|c|}{25} & \multicolumn{2}{|c|}{50} & \multicolumn{2}{|c|}{75} & \multicolumn{2}{|c|}{90} \\
\hline & LSES & USES & LSES & USES & LSES & USES & LSES & USES & LSES & USES \\
\hline 5 & 11.92 & 13.61 & - & 15.10 & - & 16.01 & - & 17.01 & - & 22.31 \\
\hline 6 & 12.68 & 12.95 & - & 14.90 & - & 16.24 & 17.34 & 16.77 & - & 18.21 \\
\hline 7 & 13.52 & 12.58 & 14.46 & 15.23 & 15.84 & 16.17 & 16.69 & - & 20.17 & - \\
\hline 8 & 13.19 & 13.29 & 14.48 & 15.12 & 16.05 & - & 16.78 & 17.37 & 18.74 & 24.71 \\
\hline 9 & 12.68 & 13.11 & 15.70 & 14.97 & 15.93 & 16.14 & 17.19 & - & 20.58 & 22.14 \\
\hline 10 & 14.06 & - & 14.7 & - & 15.64 & - & 16.90 & - & - & 19.28 \\
\hline
\end{tabular}

\section{PREVALENCE OF OVERWEIGHT AND OBESITY AMONG SELECTED SUBJECTS}

Children from both socioeconomic groups were categorised on the basis of BMI into normal, overweight and obese. The age wise prevalence of normal, overweight and obese boys and girls form LSES and USES is shown in Tables 8 and 9. It was shown in the Figure -1 and 2.

Table 8 Prevalence of Normal, Overweight and Obese Boys from LSES and USES for Ages 5 - 10 Years.

\begin{tabular}{|c|c|c|c|c|c|c|c|c|c|c|}
\hline \multirow[b]{2}{*}{$\begin{array}{c}\text { Age } \\
\text { in } \\
\text { years }\end{array}$} & \multirow[b]{2}{*}{$\mathbf{N}$} & \multicolumn{3}{|c|}{ LSES boys $(\mathrm{n}=56)$} & \multirow[b]{2}{*}{$\mathbf{N}$} & \multicolumn{3}{|c|}{ USES boys $(n=59)$} & \multirow[b]{2}{*}{$\begin{array}{l}\text { Chi square } \\
\text { value }\end{array}$} & \multirow[b]{2}{*}{$P$ value } \\
\hline & & $\begin{array}{l}\text { Normal } \\
\mathbf{N}(\%)\end{array}$ & 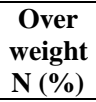 & $\begin{array}{l}\text { Obese } \\
\mathbf{N}(\%)\end{array}$ & & $\begin{array}{l}\text { Normal } \\
\mathbf{N}(\%)\end{array}$ & $\begin{array}{c}\text { Over } \\
\text { weight } \\
\mathbf{N}(\%)\end{array}$ & $\begin{array}{l}\text { Obese } \\
\mathbf{N}(\%)\end{array}$ & & \\
\hline 5 & 5 & $\begin{array}{c}5 \\
(100) \\
\end{array}$ & - & - & 7 & $\begin{array}{c}6 \\
(85.7) \\
\end{array}$ & $\begin{array}{c}1 \\
(14.3) \\
\end{array}$ & - & 57.41 & $<0.001$ \\
\hline 6 & 8 & $\begin{array}{c}8 \\
(\mathbf{1 0 0}) \\
\end{array}$ & - & - & 10 & $9(90)$ & $1(10)$ & - & 176.4 & $<0.001$ \\
\hline 7 & 12 & 11 (91.7) & $1(8.3)$ & - & 11 & $11(100)$ & - & - & 220.4 & $<0.001$ \\
\hline 8 & 14 & $14(100)$ & - & - & 14 & 13 (92.9) & - & $1(7.1)$ & 26.03 & $<0.001$ \\
\hline 9 & 12 & $12(100)$ & - & - & 9 & $6(66.7)$ & $2(22.2)$ & $\begin{array}{c}1 \\
(11.1)\end{array}$ & 168.5 & $<0.001$ \\
\hline 10 & 5 & $4(80)$ & - & 1(20) & 8 & $2(25)$ & $4(50)$ & $2(25)$ & 3.419 & $<0.001$ \\
\hline
\end{tabular}

Table value $=\mathbf{5 . 9 9 1}$ at $5 \%$ level of significance

The overall prevalence of overweight and obesity among the LSES boys showed no significant in 5and 6 years of age but USES boys were 14.3 percent significant of overweight $(\mathrm{P}<0.001)$ at 5 year of age and 10 percent of significant of overweight $(\mathrm{P}<0.001)$ at 6 year of age. Among the age groups prevalence of overweight and obesity among 7-8 years of LSES boys 8.33 percent were overweight. But there is no marked significant difference between 7-8 years among USES. Among the different age groups prevalence of overweight and obesity among 9-10 years of LSES boys only 20 percent were overweight $(\mathrm{P}<0.001)$ and $9-10$ year old USES boys 22.2 and 50 percent were overweight, $(\mathrm{P}<0.001) 11.1$ percent and 25 percent were obesity $(\mathrm{P}<0.001)$ showed higher prevalence of overweight compared to other age groups. 
Figure - 1

PREVALENCE OF NORMAL, OVERWEIGHT AND OBESE BOYS FROM LSES AND USES FOR AGES 5 - 10 YEARS

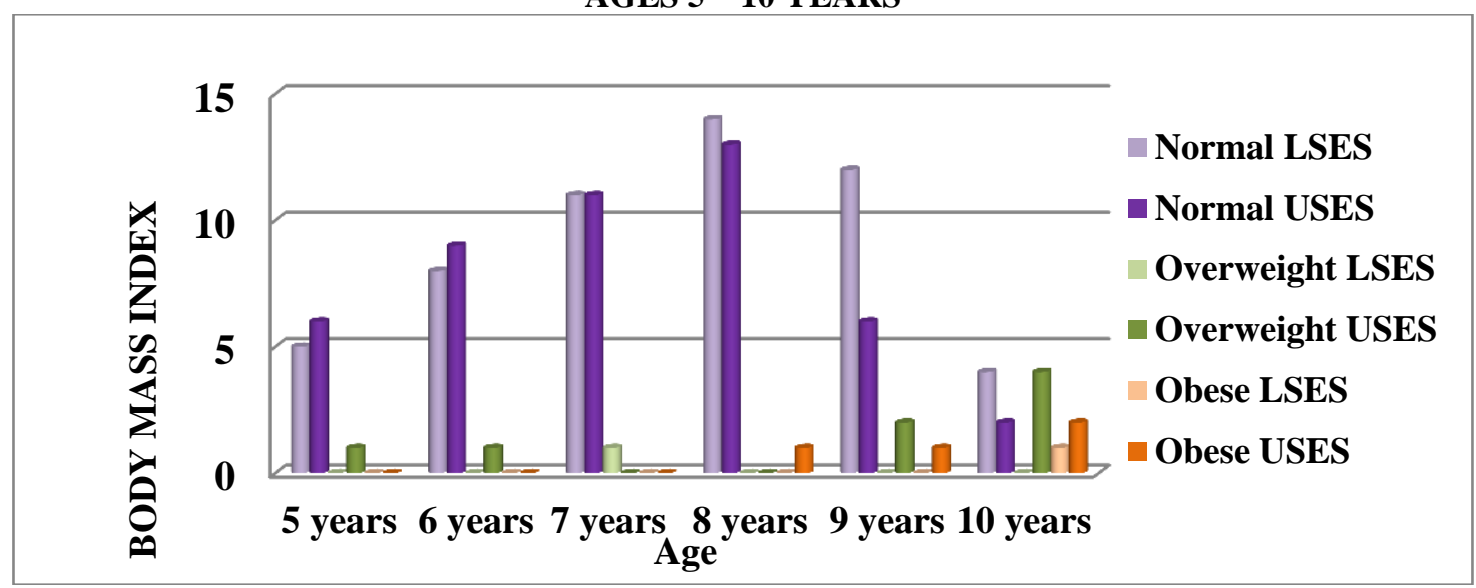

Table 9 Prevalence of Normal, Overweight and Obese Girls from LSES and Uses for Ages 5 - 10 Years.

\begin{tabular}{|c|c|c|c|c|c|c|c|c|c|c|}
\hline \multirow[b]{2}{*}{$\begin{array}{l}\text { Age } \\
\text { in } \\
\text { years }\end{array}$} & \multirow[b]{2}{*}{$\mathbf{N}$} & \multicolumn{3}{|c|}{ LSES girls $(n=69)$} & \multirow[b]{2}{*}{$\mathbf{N}$} & \multicolumn{3}{|c|}{ USES girls $(\mathrm{n}=66)$} & \multirow[b]{2}{*}{$\begin{array}{l}\text { Chi } \\
\text { square } \\
\text { value }\end{array}$} & \multirow[b]{2}{*}{$P$ value } \\
\hline & & $\begin{array}{c}\text { Normal } \\
\mathbf{N}(\%)\end{array}$ & $\begin{array}{c}\text { Over } \\
\text { weight } \\
\mathbf{N}(\%)\end{array}$ & $\begin{array}{l}\text { Obese } \\
\mathbf{N}(\%)\end{array}$ & & $\begin{array}{c}\text { Normal } \\
\mathbf{N}(\%)\end{array}$ & $\begin{array}{c}\text { Over } \\
\text { weight } \\
\mathbf{N}(\%)\end{array}$ & $\begin{array}{l}\text { Obese } \\
\mathbf{N}(\%)\end{array}$ & & \\
\hline 5 & 3 & $3(100)$ & - & - & 18 & $16(88.9)$ & - & $2(11.1)$ & 16.65 & $<0.001$ \\
\hline 6 & 6 & $6(100)$ & - & - & 11 & $10(91)$ & $1(9)$ & - & 275.18 & $<0.001$ \\
\hline 7 & 24 & 22 (91.6) & $1(4.2)$ & $1(4.2)$ & 5 & $5(100)$ & - & - & 29.85 & $<0.001$ \\
\hline 8 & 9 & 7 (77.8) & 1 (11.1) & 1 (11.1) & 11 & $10(91)$ & - & $1(9)$ & 204.4 & $<0.001$ \\
\hline 9 & 22 & $20(91)$ & $1(4.5)$ & $1(4.5)$ & 15 & $8(56.33)$ & $2(13.32)$ & $\begin{array}{c}5 \\
(33.3) \\
\end{array}$ & 34.71 & $<0.001$ \\
\hline 10 & 5 & $3(60)$ & $1(20)$ & $1(20)$ & 6 & - & $3(50)$ & $3(50)$ & 4.96 & $<0.001$ \\
\hline
\end{tabular}

Table value $=\mathbf{5 . 9 9 1}$ at $5 \%$ level of significance

The overall prevalence of overweight and obesity among the LSES girls showed no significant in 5and 6 years of age but USES girls were 11.1 percent significant of obesity $(\mathrm{P}<0.001)$ at 5 year of age and 9 percent of significant of overweight $(\mathrm{P}<0.001)$ at 6 year of age. Among the age groups prevalence of overweight and obesity among 7-8 years of LSES girls 4.2 percent were overweight and 11.1 percent were obesity at both age group. But there is no marked significant difference between 7-8 years among USES. Among the different age groups prevalence of overweight and obesity among 9-10 years of LSES girls 4.5 percent were overweight and obesity $(\mathrm{P}<0.001), 20$ percent were overweight and obesity $(\mathrm{P}<0.001)$ and 9-10 year old USES girls 13.33 and 50 percent were overweight, $(\mathrm{P}<0.001) 33.3$ percent and 50 percent were obesity $(\mathrm{P}<0.001)$ showed higher prevalence of overweight compared to other age groups.

Figure - 2

PREVALENCE OF NORMAL, OVERWEIGHT AND OBESE GIRLS FROM LSES AND USES FOR AGES 5 - 10 YEARS

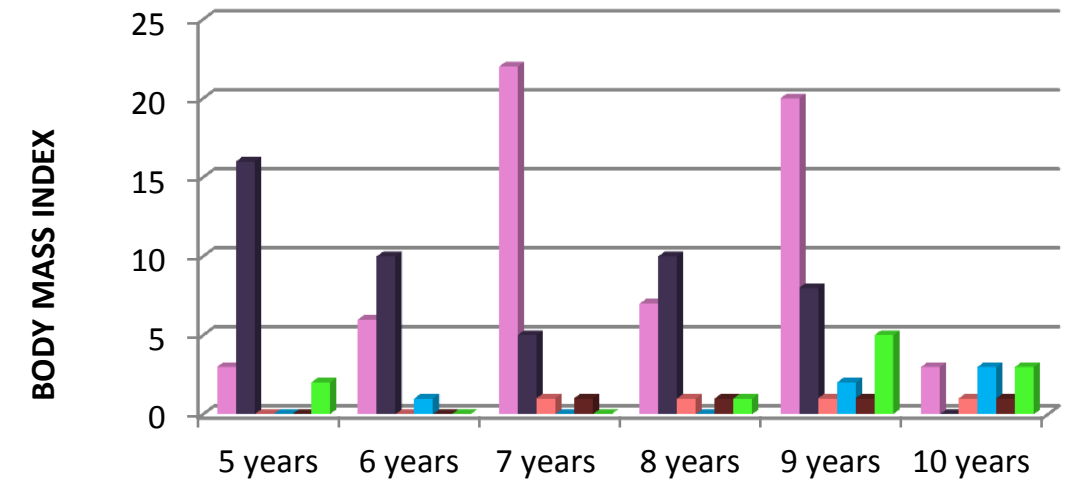

Normal LSES

- Normal USES

Overweight

LSES

Overweight USES

Obese LSES

Age 


\section{Conclusion}

It can be concluded from the above findings that the nutritional status of children were not satisfactory. The present study was planned to evaluate in detail, the complete spectrum of childhood obesity and compare the prevalence in two different socio-economic strata. This study also brings out clearly the significant difference in percentiles of height, weight and BMI in children from different socioeconomic strata at $5-10$ years in both genders. This significant disparity in anthropometric parameters between the two socio economic strata highlights the difficulty in creating one set of national norms. It is now emerging convincingly that the genesis of these disorders begins in childhood, with the childhood obesity serving as an important factor. In recent years, Type 2 diabetes is beginning to emerge even in children.

\section{References}

[1]. "Alberta Health Service | Population and Public Health Childhood overweight and obesity": Evidence from the Cost of Obesity in Alberta for 2005 Report, P.1-26.

[2]. http://www.cdc.gov/healthyweight/assessing/bmi/childrens_BMI/about_childrens_BMI.html

[3]. http://www.studymode.com/essays/The-Causes-And-Effects-Of-Childhood-799048.html 2011

[4]. Mahajan. P. B, et al, (2011), "Study of childhood obesity among school children aged 6 - 12 years in union territory of Puducherry", Indian Journal of Community Medicine.

[5]. Mahshid Dehghan. et al, (2005), "Childhood Obesity, Prevalence and Prevention”, Nutrition Journal, Vol. 4.

[6]. Manu Raj \& Krishna Kumar. R, (2010), "Obesity in children \& adolescents", Indian Journal of Medical Research, published by Amrita Institute of Medical Sciences \& Research Centre Kochi, Kerala, India, P. 598-607.

[7]. Manu Raj \& Krishna Kumar. R, (2010), "Obesity in children \& adolescents”, Indian Journal of Medical Research, published by Amrita Institute of Medical Sciences \& Research Centre Kochi, Kerala, India, P. 598-607.

[8]. Medhi. G. K, Barua. A and Mahanta. J, (2006), "Growth and Nutritional Status of School Age Children (6-14 Years) of Tea Garden Worker of Assam", Journal of Human Ecology, Vol.19, (2), P. 83-85.

[9]. Ogden et al, (2010), "Relationship Between Poverty and Overweight or Obesity", published by Food Research and Action Center.

[10]. Peckenpaugh, (2007), "Nutrition Essential and Diet Therapy", $11^{\text {th }}$ edition, published by Saunders Elsevier, P.209 - 251.

[11]. Ponni Syamala. A and Dorothy Jaganathan, ( 2012), "Health Status of Adolescents in Selected Districts of Tamil Nadu", International Journal of Health Sciences and Research,Vol.2; Issue: 7, P 54-62.

[12]. Prema Ramachandran \& Hema S. Gopalan, (2011), “Assessment of nutritional status in Indian preschool children using WHO 2006 Growth Standards”, Indian Journal of Medical Research, published by Nutrition Foundation of India, P. 47-53.

[13]. Saraswathi. Y. S, et al, (2011), "Prevalence of Childhood Obesity in School Children from Rural and Urban Areas in Mysore, Karnataka, India", Journal of Life Science, Vol. 3(1), P. 51-55.

[14]. Starthealthystayhealthy.in

[15]. Supreet Kaur. MD, et al, (2008), "Prevalence of Overweight and Obesity amongst school children in Delhi, India", Asia Pacific Journal of Clinical Nutrition, Vol. 17, P. 592-596.

[16]. Swati Bhardwaj et al, (2008), "Childhood obesity in Asian Indians: a burgeoning cause of insulin resistance, diabetes and sub clinical inflammation" review article, Asia Pacific Journal of Clinical Nutrition, Vol.17, P. 172-175. 